\title{
CONCEPTUAL PRINCIPLES OF DECENTRALIZATION OF TERRITORIAL COMMUNITY MANAGEMENT
}

\author{
Novikova N. L., Ruschenko R. Ye.
}

\section{INTRODUCTION}

Reforming the territorial organization of government and local selfgovernment, socio-economic development of the country in the face of permanent negative external challenges are priority directions of public administration and management of local development in Ukraine. The socio-political, socio-demographic and financial, and economic realities of today are pushing for ways to dramatically improve existing models of governance at the local level. The global experience proves that the dynamic development of territorial communities as a whole cannot be ensured without decentralization of public administration and without capable local self-government. Local governments in Ukraine have long been faced with challenges such as the financial and economic failure of the vast majority of communities, the actual lack of sufficient financial resources for local economic development in the respective development budgets. This situation requires scientifically sound development and implementation of mechanisms for sustainable development of territorial communities in the context of decentralization.

\section{Historical aspects of decentralization}

Studies of the phenomenon of decentralization of both domestic and foreign scholars are based on the provisions of history and theory of government. The history of decentralization dates back more than four hundred years, starting its movement in Europe in the seventeenth century. European public figures and scholars are constantly looking for new forms of administrative system of public administration and building a system of communication in the system of public authority. Despite the development of research on decentralization, by the end of the nineteenth century the majority was convinced that the main model of the state system was a strong centralized state, which in Europe was considered the ideal model of state organization. However, at the beginning of twentieth century the idea of separation of powers emerged, 
which was laid out in the papal encyclical in 1931 as a form against the highly centralized state of the Nazi, fascist and socialist formats. The main purpose of such an idea was to prevent centralized states from becoming authoritarian ${ }^{1}$. The process of decentralization of the twentieth century was characterized by the extension of powers of local authorities in various spheres, including budgetary and intergovernmental relations. According to the World Bank, 63 out of 75 transformed and developing countries, in the early and mid-1990s, began to move towards decentralization.

After the Second World War, the movement to decentralization intensified. Today it is a kind of business card of the democratic countries of Europe.

Regarding Ukraine, the ideas and practices of local self-government also have a long tradition - from the pre-state era of Eastern Slavic tribes, the eternal assembly of Kievan Rus, the introduction of the Magdeburg law, the Cossack democracy institutions, the functioning of city councils, provincial and provincial institutions, rural stairs during Ukraine as part of the Russian Empire, rural, township, townships, county and provincial commissioners, doom in the time of the UPR. The ideas of local self-government in the Ukrainian lands within the Russian and Austro-Hungarian empires, which were reformed by local authorities that were relevant to the Ukrainian population, have been developed ${ }^{2}$. The emergence of neighborhoods and the formation of settlements facilitated the development of communication and social relations on the basis of customary law. Settlement matters were discussed and approved by the council, a joint council consisting of senior representatives from all families or families. As a form of self-government, it has been passed down from generation to generation for many centuries.

In the era of Kievan Rus, the elements of self-government were vividly manifested at the level of major cities and regions and were called eternal democracy. Veche became the assembly of the free adult male population of cities that dealt with important public and state affairs. Unlike princely power, the Chamber was the bearer of the

1 Свтушенко О.Н. Демократизація державної влади i місцевого самоврядування на принципі субсидіарності: досвід Німеччини. Наукові праці Чорноморського державного університету імені Петра Могили. Серія: Політологія. 2008. Т. 93, вип. 80. С. 76-81. URL: http://nbuv.gov.ua/UJRN/ Npchdupol_2008_93_80_20.

Камінська Н.В. Місцеве самоврядування: теоретико-історичний i порівняльно-правовий аналіз : навчальний посібник. Київ, 2010. 232 с. 
democratic form of statehood. In chronicles the veche is first mentioned in Belgorod about 997, in Novgorod - 1016, in Kiev - 1068, in Volodymyr-Volynsky - in $1097^{3}$.

The urban community has enjoyed considerable administrative, economic and judicial autonomy. It owned the land and set its own rules of business, city taxes, payments and other duties. The most important issues of urban life were resolved by city councils, and for consideration of current affairs from the number of free citizens was elected by the wit and other officials of the city government. The value of the council meeting increased with the weakening of the princely power in the second half of the eleventh and during the twelfth centuries, which occurred in parallel with the economic and political uplift of large cities and the strengthening of the role of merchants and artisans. According to the level of influence, the veches acquired the character of one of the supreme authorities, which did not concede in the capitals of the stateslands to the power of the prince and the boyar council, but after the entry of Ukrainian lands into the Grand Duchy of Lithuania and Poland, this body was changed to seismic - the assembly of voivodship and county noble. These times were characterized by a complex system of interconnections between central government, city owners and urban communities, which led to the fact that in the XIII-XIV centuries communities of Ukrainian cities began to seek the right to independently resolve issues of urban life, that is, self-government, traditionally called the Magdeburg law ${ }^{4}$. The bourgeoisie as a new social layer of that time was actively involved in the state-making process, using the struggle for the granting of the Magdeburg law to gain some autonomy from the state.

The prominent Ukrainian historian M. Hrushevsky, who was critical of the role of the new system of law, remarked at the same time: "The Magdeburg right, obtained by the main Ukrainian cities in the $\mathrm{XV}$ century, severed the organic connection that connected the city with the land; the city ceased to be its center, the center of her life and turned into an enclave: Magdeburg law, assuring the city community autonomy, at the same time removed it from the administrative system of the land,

3 Яковенко Н. Нарис історії України 3 найдавніших часів до кінця XVIII століття, 1997.

${ }^{4}$ Ровинська К.I. Магдебурзьке право як підгрунтя формування місцевого самоврядування на території України. URL: http://www. kbuapa.kharkov.ua/ e-book/tpdu/2013-2/doc/3/02.pdf. 
lifted from her duties, replacing them with a personal monetary tax, intransitive boundary of the city boundary".

It should be noted that in the Ukrainian lands in the cities did not apply the classical Magdeburg law, but adapted to local conditions, its revised rules. Magdeburg law has not been formally codified, so the status of each city was determined by a set of privileges bestowed on it.

For the central power of giving a particular city of Magdeburg has become an important factor of public administration, as it expanded its social base at the expense of the townspeople. The urban population, under the cover of Magdeburg law, was protected from the arbitrariness of the royal governors and large landowners.

The local community, through Magdeburg law, has learned to govern its city on a democratic basis. She used to build a social life, less focused on central government. Urban life was introduced into clear legal rules by introducing an electoral system of local self-government bodies and the court. The activities of merchant associations and workshops, trade issues and many other areas were regulated. The autonomy of cities created favorable conditions for the development of crafts and trade.

The main result of urban self-government under the Magdeburg law can be called a successful social policy aimed at reducing poverty. Researchers point out that in the Ukrainian self-governing cities by the beginning of the eighteenth century the poverty rate was about $3 \%$. And after the Russian troops occupied most of Ukraine, increasing its burden of maintenance, this percentage increased to 20-40\%. Magdeburg law promoted the emergence of citizens who learned to manage their city, develop the city economy, elect and control power, strengthen security, establish rules of relations with the supreme power in the state. Thus, Ukrainian cities created favorable conditions for human habitation and community development, gradually becoming a single European cultural and legal space. However, the effects of Magdeburg law have not been unequivocally positive, the extension of this legal system has led to the strengthening of foreign colonization and a certain restriction of the rights of the local population.

Russian authorities in the second half of XVIII century took the course of rigid centralization in the field of administrative and territorial organization, in fact eliminated the Magdeburg law in Ukraine, and together with the German self-government. The same processes of centralization and unification management took place in Galicia, which came under the rule Austrian Empire. Ultimately, the Magdeburg Right in Kiev was abolished in 1835. 
Cossack self-government Zaporizhzhya troops formed during the second half of the XVI - end of the XVIII centuries and had numerous democratic elements: election of the Sich council, election of the government - koshova, palanka and chicken elders, koshaman, and in general affairs.

In the middle of the XVII century as a result of the national liberation war of the Ukrainian people in the territory of the Dnieper, Sivershchyna, Polissya and East Podillia, a Ukrainian Cossack state was formed the Hetmanate, which is considered as a developed state form of the Zaporizhzhia Army. Zaporizhzhya Sich did not enter the rainy of the regiments, was part of the Hetmanate on the rights of a certain autonomy, chose their own cat chieftain and subordinate directly to the hetman.

"The innovative approach of the Khmelnytsky government in establishing a new administrative structure of Ukrainian lands was that the Cossack regiments and hundreds had much smaller territories than the voivodships and counties of the Commonwealth, and therefore made it easier for administrative bodies to manage"5. The regiments and hundreds were at the same time military and administrative-territorial units and used military-administrative self-government.

Hetmanate's political regime was characterized "as a republicandemocratic one, combining elements of both direct and indirect democracy and based on a regiment-hundred administrative system" ${ }^{\text {". At }}$ the same time, the balance of powers of the main elements of the political system of the Hetmanate - the General Council, the Chief Petty Officer, the hetman and the highest elders - has undergone fundamental transformations, this "political regime in some cases acquired characteristics characteristic of authoritarian rule, in others - oligarchic".

In the second half of XIX at the beginning of XX century the Western Ukrainian lands were divided between Austria and Russia as a result of the three divisions of Poland $(1772,1793,1795)$. The lands that departed to Austria in 1772 were called the Kingdom of Galicia and Lodomeria. Halychyna was divided into Eastern (centered in Lviv) and Western (centered in Krakow).

Local government reforms in the Russian and Austro-Hungarian empires were part of a series of major reforms of the $1860 \mathrm{~s}$ and $70 \mathrm{~s}$ that

\footnotetext{
${ }^{5}$ Смолій В.А. Історія українського козацтва: нариси у двох томах. Вид. дім «Києво-Могилянська академія», 2006.

${ }^{6}$ Ibid.
} 
aimed at a profound modernization of these states. The self-governing body in Galicia was called a public council, headed by a president who relied on an executive body - the city government (in large cities magistrates). In 1889, the Halytskyi Seimas adopted a law on communities for the 30 largest cities of Galicia, and in 1896 on selfgovernment in 145 smaller cities and towns of the region was given autonomy in dealing with internal issues. In Bukovina in Chernivtsi, a regional council of 30 ambassadors started operating.

In the Ukrainian lands that were part of the Russian Empire, selfgoverning bodies at the level of village-parish, province-county and city were created as a result of peasant (1861), Zemsky (1864) and city (1870) respectively reform.

Self-government in the countryside was regulated by special ones by the General Regulations of February 19, 1861, and since 1902, the "Regulations on the Rural Status" (taxes, social security, decimals), resolved small land and police cases, distributed taxes. But of great importance in the self-government of the peasants played the district east, which consisted of village and town officials, headed by the district chairman, as well as "ten-yarders" - elected in each ten yards.

Significant influence on the social life of Ukraine was carried out in 1864 by Alexander II Zemsky Reform. According to the Provincial and County Provincial Regulations, the Zemstvos Institute was established. Initially, they were introduced in the southern and left bank provinces. Due to the Polish uprising of 1863, the Right-wing Ukrainian Reform was carried out here only in 1911.

In the European part of the Russian Empire, including the Left Bank and Slobid Ukraine, Zemsky institutions were established as bodies of regional (at county and provincial level) self-government. According to the law zemstvo consisted of representative bodies (county and provincial assemblies), which worked in session, and executive bodies on a permanent basis (county and provincial administrations), communication, distribution of state budget funds, collection and submission to the state bodies of statistical materials, maintenance of local roads, provision of food to the population in case of famine.

Further reform of local self-government took place in accordance with the City Regulations of 1870 , which was introduced in nine provincial and similar cities of Ukraine, and in other cities, the reform was carried out at the discretion of the Minister of Internal Affairs, taking into account local peculiarities. 
In 1892, a new City Regulation was approved. First, the changes took place in the electoral system and in the status of local self-government bodies. Voting rights were obtained in the county cities of persons who owned real estate worth at least three hundred rubles, in the provincial from one thousand to one and a half thousand rubles a year and paid taxes to the city treasury. In general, about $2 \%$ of the population got the right to vote.

Among the achievements of that reform is the experience of publicity of doom: all decisions and resolutions of the doom, the city budget, the report on its implementation, the reports of management were subject to publication. Negative in their activities was the low attendance of the Duma meetings, lack of initiative of the vowels. In general, the implementation of this reform has contributed to the increase in urban revenues, the government has been able to translate into self-government a large part of the cost burdensome for the central government.

As in the era of the Magdeburg right to grant autonomy to the citizens in the late nineteenth century contributed to their rapid development, which occurred in all areas of urban life and economy. The economic basis for the prosperity of cities was industry and commerce, and organizational and managerial activity was the activity of city councils. The most developed at that time were Kyiv, Katerynoslav, Kharkiv, Odessa, Lviv, which showed other Ukrainian cities an example of modernization. In government of the city are involved and make a significant contribution to famous businessmen, engineers, scientists, public figures, patrons.

Local self-government in Russia has given impetus to development, however after 1907 the centralization and the withdrawal of the European model began again. The government did not trust the electoral mindsets because they could be an example to society of the success of self-government and indirectly served to disseminate ideas of restriction on royal power.

The main drawback of the reform was the desire of the central government to control local government initiatives and the continued lack of funding. In addition, rapid industrialization, which began in the late XIX - early XX centuries, led to a rapid increase in urban population. As a result, serious social problems arose that could not be solved without further profound transformations of the empire.

Russian imperial national policy, which did not recognize Ukrainians as a separate nation, led to the rapid Russification of large industrial cities. With the assistance of the policies of the state administrations of 
Russia and Austria-Hungary, local governments were non-Ukrainian in Ukrainian cities. Documentation was conducted in the Ukrainian lands of the Russian Empire - in Russian, and in the Ukrainian territories of Austria-Hungary - in German and Polish.

But the most fundamental problem of doom was that they relied on a very small number of city voters (1-2\%). During the Revolution of 1917, the Provisional Government planned to reform, organizing elections on the basis of universal, secret, direct and equal voting. It was stated that the bulk of the local authority would be given not to the state, but to the new local authorities.

The formation of the system of local self-government during this period contributed to the political experience of the Ukrainian elite. And in the storms of revolutionary events, the Duma was the only more or less real power in the field, who cared about the inhabitants and kept the urban economy.

Independent Ukrainian governments in the 1917-1920's tried to reform local self-government, trying to Ukrainize it. The universals of the Central Rada, along with the need for local self-government reform, emphasized its continuity and the evolutionary nature of local authority change.

Decentralization in Ukraine was first mentioned in the Constitution of the Ukrainian People's Republic in 1918, which stated, in particular, that without violating its sole authority, the Ukrainian People's Republic grants its lands and communities broad self-government rights in accordance with the principle of decentralization.

Thus, the Constitution of the UNR in 1918 approved the principles of decentralization: land, parishes and communities were granted the rights of broad self-government, organizational autonomy. However, with the change of government in Ukraine, they have not been implemented.

Moreover, after the defeat of the Ukrainian Revolution, Bolshevism established the communist dictatorship, in which local self-government was destroyed not only as an idea but also as a way of a democratic society. The term "local self-government" was also banned, and instead "council power" was introduced, which was called "democracy". At the same time, it gained new opportunities for development in Western democracies, especially after the Second World War.

After 70 years of destroying local self-government and ignoring the interests of communities, the state has recognized their importance and announced a new policy to revive self-government. One of the wellknown steps of the Ukrainian SSR was the adoption by the new 
composition of the Verkhovna Rada on December 7, 1990 of the law "Provincial Council of People's Deputies and Local and Regional SelfGovernment".

The legal foundations of local self-government in Ukraine were enshrined in the 1996 Constitution and subsequent laws, including the European Charter of Local Self-Government, to which Ukraine joined. On June 28, 1997, the Law of Ukraine "On Local Self-Government in Ukraine" was adopted, which defined the system and guarantees of local self-government, the principles of organization and activity, legal status and responsibility of bodies and officials of local self-government, based on world experience and national.

\section{Decentralization reform in Ukraine}

Formally, the decentralization reform initiated in Ukraine in 2014 with the adoption of a number of legislative acts, in our deep conviction, proved to be the most relevant and socially demanded. The fact is that since the beginning of the independence of the Ukrainian state, a number of fundamental reforms have been initiated and implemented in different years, which have influenced and influence the development and functioning of many social institutions of economic and political processes in Ukraine. But, unfortunately, this change in no way affected the quality of life of our country's citizens, who continued to face the same problems of a particular city, town or village: kindergartens and schools that were closed due to lack of funding, ineffective primary medical aid or in general its absence, pollution of reservoirs, lack of quality drinking water and much more. As of the beginning of 2014, Ukraine has not developed a single all-Ukrainian space - institutional, cultural, educational, information the unitary and centralized state was in fact deeply regionalized. The situation was further exacerbated by the fact that Ukraine started the 2014 reforms in the context of severe economic depletion, the loss of Crimea and the deployment of violent military confrontation in the Donbas. All this has inevitably been reflected in the content, pace and funding opportunities of reforms. The main reason that the decentralization reform in Ukraine started with the unification of territorial communities was a large number of settlements with a small number of population and the actual lack of opportunities for development, the population in rural settlements is aging, urbanization processes are taking place so the economically active part of the population rural settlements move to major cities or generally outside Ukraine. With this in mind, the state cannot guarantee quality provision 
of social and administrative services to residents. The main objective of the reform is to create conditions for community development and to bring services closer to the people through the formation of wealthy communities, the transfer of most of the powers to the basic level of government and a clear separation of functions between levels of government, and to ensure the proper resourcing of local selfgovernment.

Regarding the theoretical and methodological bases of the term "decentralization", it comes from the term "centralization", which in turn means concentration of management, management in a single center ${ }^{7}$, or concentration of most state functions under the authority of central institutions ${ }^{8}$.

Based on this understanding of "centralization" and the prefix "where" indicating the removal, isolation, termination, cancellation of something, or downward movement ${ }^{9}$, in the dictionary literature the term "decentralization" is characterized as the destruction, cancellation, or weakening of centralization ${ }^{10}$.

Thus, we state that the term "decentralization" is the opposite of the term "centralization". However, if we consider decentralization as a process, then, according to most scholars, the existence of any state necessarily implies that such cases are necessarily managed by the center.

In particular, domestic scientists O. Baymuratov, L. Boryslavskyi, V. Bordeniuk, Y. Shemshuchenko and others emphasize that we are talking only about the optimal relationship between these phenomena of social life. Without a proper combination of centralization and decentralization, no management can objectively exist and therefore cannot be opposed. Centralization is an integral feature of statehood, and constitutional changes should not pose a risk to statehood. This is guaranteed, on the one hand, by the monopoly of the state in certain spheres (national security and defense, monetary issue, citizenship issues, etc.) and, on the other, by the existence of state control over the

7 Словник іншомовних слів / за ред. О.С. Мельничука. Київ : Головна редакція УРЕ, 1977. $776 \mathrm{c.}$

${ }^{8}$ Великий тлумачний словник сучасної української мови / уклад. і гол. ред. В.Т. Бусел. Київ; Ірпінь : ВТФ «Перун», 2004. 1440 с.

9 Тлумачний словник української мови / за ред. В.С. Калашника. 2-ге вид., випр. і доп. Харків : Прапор, 2004. 992 с.

${ }^{10}$ Великий тлумачний словник сучасної української мови / уклад. і гол. ред. В.Т. Бусел. Київ; Ірпінь : ВТФ «Перун», 2004. 1440 с. 
legality and constitutionality of the functioning of local self-government entities (because, to some extent, it is also a matter of national security).

A. Krusyan is of the same opinion, emphasizing that: "...the main expected consequences of decentralization of public power in Ukraine are its transformation in order to democratize public administration $<\ldots>$ which in modern conditions for Ukraine is a guarantee of preserving its territorial integrity, stabilizing socio-political stability situation and, at the same time, the constitutional and legal basis of further development as a democratic rule of law"11.

The authors of Decentralization in Ukraine: Legislative Innovation and Public Expectations also emphasize the importance of "empowering those bodies that work closest to the people and can solve local problems as effectively as possible, that is, taking full account of the subsidiarity principle envisaged by the European Harmonization Framework selfgovernment ratified by Ukraine in 1997"12.

The scientist V. Bordeniuk distinguishes between horizontal (distribution of powers between the relevant state bodies functioning at the same level of organization of state power) and vertical (distribution of powers between the central bodies of the state and bodies created at different levels of the territorial organization of the state).

Thus, analyzing the views of scientists on the phenomenon of "decentralization", we want to note that the researchers have not come to a unified definition. For example, Japanese researcher N. Kavashima defines the phenomenon of decentralization as the art of government. The French scientist J.-B. Albertini views her as state policy. V. Demidenko defines the above phenomenon as the basis of the principle of Western European and world politics ${ }^{13}$.

Decentralization is defined by $M$. Lendiel as an overriding requirement for the functioning of such political assessments as independence, openness, accountability and quality of public institutions. Decentralization is recognized as an extremely common phenomenon in public administration (F. Melnik). According to K. Linov

11 Крусян А. Всеукраїнський форум учених-правознавців «Новітній конституиійний процес в Украӥні: питання децентралізації влади». Право. Вісник. Додаток до журналу «Право Украӥни». Київ : Ін Юре, 2015. С. 46-49.

${ }^{12}$ Європейська хартія місцевого самоврядування : Документ Ради Європи від 15 жовтня 1985 p. URL: http://zakon5.rada.gov.ua/laws/show/994_036 (Last accessed: 03.09.2016).

${ }^{13}$ Борденюк В. Децентралізація державної влади і місцеве самоврядування: поняття, суть та форми (види). Право Украӥни. 2005. № 1. С. 21-25. 
decentralization is a necessary component in the process of democratization of the state ${ }^{14}$. Researcher B. Gourne understands decentralization as a way of territorial organization of state power ${ }^{15}$. E. Shaikhislamov explains it as a set of methods and methods of transferring the balance of power. M. Bagmet and T. Lichko. $\mathrm{V}$. Andrushchenko understand that it is an effective model of public organization. M. Bratkovsky, O. Kremen assesse it as an extended process. They are supported by N. Meltyukhov and Y. Vanina, focusing on the systematic and purposefulness of this process.

G. Odintsova, O. Amosov, and G. Mostovoy gave their understanding of decentralization as autonomy in the methods of public administration, taking into account the diversity of local characteristics, while maintaining overall unity in the basic and essential ${ }^{16}$. The scientist J.-M. Bese defines decentralization as a simple, indivisible mechanism of governance. This multifaceted semantics of the phenomenon analyzed above explains the lack of a unified approach to understanding it.

As a delegation of powers, the phenomenon of "decentralization" is represented in the scientific developments of such researchers as: O. Prieshkina, V. Bordeniuk, M. Budnik, I. Grytsyak. As a system of delegation and responsibility considered the above phenomenon, British researchers, G. Breban, international experts, M. Dobrinin, D. Zhovtun.

The American researcher A. Rosenbaum broadly views the category of "decentralization" and emphasizes that it is an increase in power; organization of effective management system; effective mechanism of checks and balances in the middle of state power; a means of encouraging the governance of citizens and civic organizations ${ }^{17}$. Decentralization is not a mechanical transfer of powers from state to local governments. It is a complex and complex process that aims at forming a new quality of state power, creating new institutions, developing a private initiative, actively involving citizens in managing

14 Линьов К.О. Централізація, децентралізація та нелінійність у державному управлінні: автореф. дис. ... канд. держ. упр.: 25.00.01. Київ, 2004. 20 с.

${ }^{15}$ Гурне Б. Державне управління /пер. 3 фр. Київ : Основи, 1993. 165 с.

${ }^{16}$ Одінцова Г.С., Мостовий Г.І., Амосов О.Ю. та ін. Державне управління і менеджмент : навчальний посібник у табл. і схемах / за заг. ред. Г.С. Одінцової. Харків : ХарРІ УАДУ, 2002. 492 с.

17 Розенбаум А. Демократія, урядування і децентралізація. Проблеми стосунків між рівнями влади крізь призму українського законодавства. Вісник Програми сприяння парламентові України. 1998. 17 груд. С. 12-15. URL: http://pdp.org.ua/analytics/authorities/933-168-a4. 
their territories of residence, and, as a consequence, improving the living space of citizens. It is a peculiar development of civil society (creation of political, financial, administrative infrastructure) by the state itself by transferring to taxpayers the right to dispose of paid funds at their own discretion and under their own responsibility.

We also emphasize that the transfer of state part of the powers of executive bodies to local self-government bodies is in the interests of the population, taking into account the principle of subsidiarity, that is, in such a way as to delegate powers to the level of government closest to the citizen, which is more capable of performing this power than others authorities. In doing so, the transfer of the necessary resources must be ensured and the right of the local self-government authority to be decided on the basis of the local characteristics. Under these conditions, the central authorities still reserve the right to monitor the quality of service provision and make necessary adjustments.

The reform of local self-government in Ukraine affects not only the form of public administration but also the constitutional system in Ukraine. In the Ukrainian legislation, a new form appears in the administrative-territorial structure of the state - united territorial communities. The first experimental united territorial communities began with to appear in late 2014 in early 2015. Initially, the topic did not gain wide popularity due to the socio-political situation in the country. Most opinion polls on territorial community unification were conducted on the eve of the first elections in individual territorial communities, such surveys are closed in nature and used during election campaigns. Opensource research on a given topic, published by individual sociological companies at the request of foreign agencies and public authorities. In particular, all-Ukrainian studies were conducted by the Kiev International Institute of Sociology at the request of the Council of Europe Program "Decentralization and Territorial Consolidation of Ukraine"18. In order to prepare an information campaign on the implementation of the decentralization reform, the Swiss-Ukrainian project "Supporting decentralization in Ukraine" has conducted a series of qualitative studies (focus groups) to gather and analyze the widest possible range of public opinion regarding decentralization ${ }^{19}$. A series of

18 Децентралізація та територіальна консолідація України. URL: http://www.slg-coe.org.ua/.

19 Швейцарсько-український проект «Підтримка децентралізації в Україні» DESPRO. URL: despro.org.ua/. 
studies were conducted by the Razumkov ${ }^{20}$ Center, relevant to the study of public opinion on decentralization, Sotsis Center ${ }^{21}$, Rating Group ${ }^{22}$. Before implementing the decentralization reform, the impact on society and the lives of citizens in the countries where such reform was implemented was examined, namely Poland, France, Latvia and others ${ }^{23}$. A more detailed analysis of the foreign experience of decentralization will be conducted in the second section of the study. Now let us just mention that prior to the beginning of the creation of the first united communities in Ukraine, consultations with foreign experts, numerous round tables, forums, meetings, and discussions on the extension of local self-government rights were held as a basis for decentralization reform. It should be noted that decentralization reform is based on the reform of the public administration in Ukraine, initiated by the Concept of Administrative Reform, approved by Presidential Decree No. 822 of July $22,1998^{24}$.

An important factor in the reform itself is a change in the local government system and, as a consequence, a change in the outlook of residents of territorial communities. The increasing political and economic weight of officials and deputies of the united territorial communities has greatly increased the attention and interest of allUkrainian political parties in the process of unification, as well as increased the attention of local groups of elites, active citizens and civic organizations.

As noted in the conclusions and recommendations of the AllUkrainian Forum of Law-Scientists "The Newest Constitutional Process in Ukraine: Issues of Decentralization of Power". Therefore, the problems of reforming the administrative and territorial structure are of

20 «Росія почала продукувати ідеї федералізації України»: інтерв’ю 3 Віктором Мусіякою. URL: http://razumkov.org.ua/statti-ta-interviu/rosiia-pochalaprodukuvaty-idei-

${ }^{21}$ Результаты социологического исследования. URL: http://old.socis.kiev.ua/ ua/press/rezultaty-sotsyolohycheskoho- yssledovanyja-avhust-2014.html

22 Настрої та очікування українців: регіональні особливості. URL: http://ratinggroup.ua/research/ukraine/nastroeniya_i_ozhidaniya_ukraincev_regio.

23 Децентрализация: анализ европейского опыта (инфографика). URL: https://www.segodnya.ua/lifestyle/fun/decentralizaciya-analiz-evropeyskogo-opytainfografika-658161.html.

24 Костюк Т.С. Творча робота: «Децентралізація влади: модель для України». URL: http://kds.org.ua/blog/kostyuk-ts- tvorcha-robota-detsentralizatsiyavladi-model-dlya-ukraini. 
particular importance in the current context. First of all, this is due to the fact that the existing administrative-territorial division no longer corresponds to the socio-political and economic realities that have formed in Ukraine, and, above all, to the principles of building a constitutionally-decentralized state" ${ }^{, 25}$.

However, again, it should be noted that the issue of decentralization of power is not justified only in the administrative-territorial reform. It can be a great opportunity to prepare the ground for self-management of the community through their own affairs, the ability to implement new initiatives and neutralize conformism and established practices, beginning a period of greater transparency of government. In fact, it is a reform of society. Therefore, it is important to get the widest possible support. In many cases, the strongest opponents can become the best supporters when they have a clear understanding of the value of new opportunities that open up to society" 26 .

The same opinion, only in a slightly different aspect, supports the Ukrainian scientist A. Kalinkin, who says that decentralization cannot be narrowed down to a territorial decision-making organization, should be excluded from the structure of the executive power, because it is inherent in the whole system of democratically organized public power ${ }^{27}$. Decentralization characterizes the process of transformation of the mechanism of exercising power in the public administration, which consists of the management subsystem (entities) and the controlled subsystem (management objects), as well as the constant interaction of entities and management objects.

\section{CONCLUSIONS}

Thus, it is worth noting that the phenomenon of decentralization covers a wide range of problems related to issues of democracy development, reorganization of power systems, search for effective tools for regulating the economy, development of self-organization of citizens,

25 Всеукраїнський форум учених правознавців «Новітній конституичійний процес в Україні: питання децентралізації влади». Право. Вісник. Додаток до журналу «Право України». Київ : Ін Юре, 2015. 93 с.

26 Делькамп Алан. Децентралізація влади - ключове питання конституційної реформи. Всеукраїнський форум учених-правознавців «Новітній конституиійний процес в Україні: питання децентралізації влади». Право. Вісник. Додаток до журналу «Право України». Київ : Ін Юре, 2015. С. 15-16.

27 Калінкін А.С. Конституційна реформа у сфері децентралізації державної влади: проблеми теорії та практики : дис. ...канд. юрид. наук. Київ, 2016. 198 с. 
etc. It is multifaceted, complex both in structure and in content, analyzing which defines certain generalizations, namely: the state carries out the decentralization of power in the interests of its citizens; the process of transferring some of the powers of the executive authorities to the local self-government bodies should take into account the level of governance that is most close to the citizen, which will perform them more effectively (subsidiarity principle); the transfer of resources to fulfill the delegated powers must be ensured, as well as the right of the local self-government authority to decide on the delegated powers, taking into account local characteristics.

Since Ukraine's independence, a number of reforms have been implemented in different years that affect the functioning of many economic and political processes in Ukraine. But these changes did not affect the quality of life of ordinary citizens who continued to face the same problems of a particular city, town or village: kindergartens and schools that were closed due to lack of funding, ineffective primary care, or none at all, pollution of reservoirs, lack of quality drinking water and much more. Therefore, the most pressing and socially demanded reform has been the reform of local self-government in Ukraine, which influences not only the form of public administration but also the constitutional system in Ukraine. At present, $70 \%$ of the population and $40 \%$ of the territory live in decentralized, dynamic Ukraine. Ukrainian ATGs build kindergartens, repair schools, engage in safety, promote original local produce. It is difficult to predict how united territorial communities can seize the opportunities that their decentralization and understanding of their participation in territorial development truly offers. Such an understanding depends on the productivity and the search for common solutions between public authorities, local governments and community representatives. At present, it is not clear what social model will be in the united territorial communities and what is the final tax base for the budget revenues. Failure to do so clearly could lead to negative consequences, such as reverse separation processes or other social outbursts.

\section{SUMMARY}

The article describes the theoretical foundations of the development of territorial communities in the context of the decentralization process. The views of scientists on the phenomenon of "decentralization" have been analyzed and summarized. Given modern approaches to considering decentralization, the theory of government focuses on the 
characteristics of the process of decentralization. The peculiarities of the process of decentralization in Ukraine are analyzed. It is determined that it is a complex and complex process that aims at forming a new quality of state power, creating new institutions, developing a private initiative, actively involving citizens in managing their territories of residence, and, as a consequence, improving their living standards space of citizens. It is a peculiar development of civil society (creation of political, financial, administrative infrastructure) by the state itself by transferring to taxpayers the right to dispose of paid funds at their own discretion and under their own responsibility.

\section{REFERENCES}

1. Свтушенко О.Н. Демократизація державної влади і місцевого самоврядування на принципі субсидіарності: досвід Німеччини. Наукові праці Чорноморського державного університету імені Петра Могили. Серія: Політологія. 2008. Т. 93, вип. 80. С. 76-81. URL: http://nbuv.gov.ua/UJRN/Npchdupol_2008_93_80_20.

2. Камінська Н.В. Місцеве самоврядування: теоретикоісторичний і порівняльно-правовий аналіз : навчальний посібник. Київ, 2010. 232 с.

3. Яковенко Н. Нарис історії України з найдавніших часів до кінця XVIII століття, 1997.

4. Ровинська К.І. Магдебурзьке право як підгрунтя формування місцевого самоврядування на території України. URL: http://www. kbuapa.kharkov.ua/e-book/tpdu/2013-2/doc/3/02.pdf.

5. Смолій В.А. Історія українського козацтва: нариси у двох томах. Вид. дім «Києво-Могилянська академія», 2016.

6. Смолій В.А. Історія українського козацтва: нариси у двох томах. Вид. дім «Києво-Могилянська академія», 2016.

7. Словник іншомовних слів / за ред. О.С. Мельничука. Київ : Головна редакція УРЕ, 1977. 776 с.

8. Великий тлумачний словник сучасної української мови / уклад. і гол. ред. В.Т. Бусел. Київ; Ірпінь : ВТФ «Перун», 2004. $1440 \mathrm{c}$.

9. Тлумачний словник української мови / за ред. В.С. Калашника. 2-ге вид., випр. і доп. Харків : Прапор, 2004. 992 с.

10. Великий тлумачний словник сучасної української мови / уклад. і гол. ред. В.Т. Бусел. Київ; Ірпінь : ВТФ «Перун», 2004. $1440 \mathrm{c}$. 
11. Крусян А. Всеукраїнський форум учених-правознавців «Новітній конституиійний процес в Украйні: питання децентралізації влади». Право. Вісник. Додаток до журналу «Право України». Київ : Ін Юре, 2018. С. 46-49.

12. Свропейська хартія місцевого самоврядування : Документ Ради Європи від 15 жовтня 1985 p. URL: http://zakon5.rada.gov.ua/ laws/show/994_036 (дата звернення: 03.09.2016).

13. Борденюк В. Децентралізація державної влади і місцеве самоврядування: поняття, суть та форми (види). Право України. 2015. № 1. C. 21-25.

14. Линьов К.О. Централізація, децентралізація та нелінійність у державному управлінні : автореф. дис. ... канд. держ. упр. : 25.00.01. Київ, 2004. 20 с.

15. Гурне Б. Державне управління / пер. 3 фр. Київ : Основи, 1993. $165 \mathrm{c}$.

16. Одінцова Г.С., Мостовий Г.І., Амосов О.Ю. та ін. Державне управління і менеджмент : навчальний посібник у табл. і схемах / за заг. ред. Г.С. Одінцової. Харків : ХарРІ УАДУ, 2002. 492 с.

17. Розенбаум А. Демократія, урядування і децентралізація. Проблеми стосунків між рівнями влади крізь призму українського законодавства. Вісник Програми сприяння парламентові України. 1998. 17 груд. С. 12-15. URL: http://pdp.org.ua/analytics/authorities/ 933-168-a4.

18. Децентралізація та територіальна консолідація України. URL: http://www.slg-coe.org.ua/.

19. Швейцарсько-український проект «Підтримка децентралізації в Україні» DESPRO. URL: despro.org.ua/.

20. «Росія почала продукувати ідеї федералізації України»: інтерв'ю з Віктором Мусіякою. URL: http://razumkov.org.ua/statti-tainterviu/rosiia-pochala-produkuvaty-idei-.

21. Результаты социологического исследования. URL: http://old.socis.kiev.ua/ua/press/rezultaty-sotsyolohycheskohoyssledovanyja-avhust-2014.html.

22. Настрої та очікування українців: регіональні особливості. URL: http://ratinggroup.ua/research/ukraine/nastroeniya_i_ozhidaniya_ ukraincev_regio.

23. Децентрализация: анализ европейского опыта (инфографика). URL: https://www.segodnya.ua/lifestyle/fun/ decentralizaciya-analiz-evropeyskogo- opyta-infografika-658161.html. 
24. Костюк Т.С. Творча робота: «Децентралізація влади: модель для України». URL: http://kds.org.ua/blog/kostyuk-ts- tvorcha-robotadetsentralizatsiya-vladi-model-dlya-ukraini.

25. Всеукраїнський форум учених-правознавців «Новітній конституиійний процес в Украӥні: питання децентралізащії влади». Право. Вісник. Додаток до журналу «Право Украӥни». Київ : Ін Юре, 2015. $93 \mathrm{c}$.

26. Делькамп Алан Децентралізація влади - ключове питання конституційної реформи. Всеукраїнський форум ученихправознавців «Новітній конституиійний прочес в Украӥні: питання децентралізації влади». Право. Вісник. Додаток до журналу «Право України». Київ : Ін Юре, 2015. С. 15-16.

27. Калінкін А.С. Конституційна реформа у сфері децентралізації державної влади: проблеми теорії та практики : дис. ... канд. юрид. наук. Київ , 2016. 198 с.

\section{Information about authors: \\ Novikova N. L.,}

Doctor of Economic Sciences, Professor, Head of the Department of Public Administration Kyiv National University of Trade and Economics 19, Kioto Str., Kyiv, 02156, Ukraine

Ruschenko R. Ye., Graduate Student of the Department of Public Administration Kyiv National University of Trade and Economics 19, Kioto Str., Kyiv, 02156, Ukraine 